\title{
Analysis of Performance Appraisal Implementation on Organization Performance in Saccos: Case of Kisii County, Kenya
}

\author{
Onyiego Jacob Mongare*1 Simon Nyakwara*2 \\ 1. Masters Degree in Business Administration and Management of Mount Kenya University \\ 2. Doctor of Philosophy\& Director at Kisii Campus of Mount Kenya University
}

\begin{abstract}
Performance management is one of the important key activities performed by organizations to monitor the performance of their employees. Organizations must regularly evaluate the performance of their employees in order to understand their current and future abilities. The purpose of this paper is to assess the impact of performance management on employee and organizational performance. The study adopted a cross-sectional survey research design and involved a sample size of 120 human resource officers and managers from selected private organizations in Tanzania. Data was collected using structured questionnaires and interviews and analyzed using descriptive and inferential statistics and the results presented using tables. The findings of the study reveal that private organizations practice performance management and have effective performance management system to evaluate/appraise the performance of their employees. Moreover, the findings reveal that there is a significant relationship between performance management and employee performance as well as between performance management and organizational performance. The study recommends the need of the private organizations to maintain and continue practising and implementing effective performance management systems, also to continue evaluating the performance of their employees frequently because it helps to determine training needs and at the same time acts as a motivational strategy hence leads to a better performance of employees and organization.

Performance appraisal is the basic tendency to make an evaluation of an individual's work performance in order to arrive at objective personal decisions. It systematically reviews a person's work and achievements over a recent period, leading to plans for the future in personnel psychology. Savings and Credit Co-operative Societies (SACCOs) are voluntary associations to which members contribute regularly their pooled savings and from which they obtain loans for provident and other purposes. Generally, SACCOs are established with the objective of promoting savings and credit with training opportunities on the wise use of their funds. An extensive use of performance appraisal in SACCOs helps in the improvement of individual job performance, promote employee training and development, focus on SACCO goals, encourage teamwork, promote co-operation, improve ability of SACCOs to hire' qualified employees and enable employees determine what it takes to be successful in SACCO movement. The general objective of the study was to investigate the extent of implementation of performance appraisal in SACCOs in Kisii Central district. A descriptive survey design was adopted to conduct the study. It was relevant because it is used to assess attitudes and opinions about events, individuals or procedures. The study focused on employees of active SACCOs in Kisii Central District, Kenya. The data was collected using questionnaires, arranged and grouped according to particular research questions, tabulated and analyzed using descriptive and inferential statistics by Software Package for Social Sciences (SPSS). The study showed that a large proportion of SACCOs (76.0) lacked performance appraisal. Those SACCOS that had performance appraisal (24), carried it out once a year and it was largely conducted by the general manager. To a less extent, the performance appraisal helped the SACCOs to rate the workers strengths and weaknesses. Although it was revealed that performance appraisal helped SACCOs in overcoming challenges at work; unfortunately, many SACCOs did not use it in implementing decisions that concerned workers welfare and job mobility.
\end{abstract}

Keywords: Performance Appraisal Implementation, Organization Performance in Saccos, Kisii County in Kenya. DOI: $10.7176 / \mathrm{EJBM} / 11-29-08$

Publication date:October $31^{\text {st }} 2019$

\subsection{Background Information}

Appraisal is the systematic description of job relevant strengths and weaknesses within and between employees. It has several elements; it needs to satisfy the combined needs of individual subordinate, the manager and the general organization. Performance appraisal therefore is the basic tendency to make an evaluation of an individual's work performance in order to arrive at objective personal decisions. It systematically reviews a person's work and achievements over a recent period, leading to plans for the future in personnel psychology (Foster,. 2004).

Savings and Credit Co-operative Societies (SACCOs) are voluntary associations to which members contribute regularly their pooled savings and from which they obtain loans for provident and other purposes. Generally SACCOs are established with the objective of promoting savings, credit and with training opportunities on the wise use of their funds (Maina D.T. and Kibanga M, 2004).

The Co-operative Societies usually belonged to a District Union, which in the 1970s started providing credit and saving facilities through Union Banking Sections CUBS). This made credit and saving more accessible to the 
rural poor because the UBS did not have the same discriminating rules as the commercial banks. Because of misuse and corruption many of the Unions collapsed though. The ones that survived have almost exclusively been transformed into autonomous rural Savings and Credit Co-operatives (SACCOs), with no connection to the Unions (Carina S. and Jennie 0, 2001).

Co-operatives have played an important role in the development of the economies of Kenya, Uganda and Tanzania and have led to the uplifting of the standards of living of the people. It is estimated that there are more than 6 million Co-operative members in the Region. In Kenya there are more than 2.5 million members in Savings and Credit Co-operatives (SACCOs) out of the 5 million Co-operators while there are 3,000 SACCOs out of the 10,000 registered Co-operatives. The savings mobilized by SACCOs in Kenya are Kshs.IIO billion (US\$I.5 billion) and the loans outstanding Kshs.95 billion (US\$I.3 billion) Co-operatives have been involved in the provision of credit for the purchase of land, farm inputs, housing, education, medication and development of various business ventures. The cross-cutting issues affecting Co-operatives in the East African Region are; governance, inadequate human resource, weak regulations and supervision, limited products and services, low marketing and innovation and poor image (Mudibo E.K, 2005).

The history of performance appraisal is quite brief. Its roots in the early 20th century can be traced to Taylor's pioneering time and motion studies. But this is not very helpful, for the same may be said about almost everything in the field of modem human resources management. As a distinct and formal management procedure used in the evaluation of work performance, appraisal really dates from the time of the Second World

War. Yet in a broader sense, the practice of appraisal is a very ancient art. In the scale of things historical, it might well lay claim to being the world's second oldest profession (Becker et al., 1996).

Performance appraisal dates back to the mid 1990s and currently both public and private organizations have adopted it as an important tool of management tracking in Kenya. However, SACCOs have not fully embraced the use of performance appraisal as an important tool of improving the upward mobility, training and development of individual employees. In addition performance appraisal would enable SACCOs to focus on their goals, encourage teamwork, improve ability of SACCOs to hire better-qualified employees and enable employees to determine what it takes to be successful in SACCO movement (Maina D.T. and Kibanga M,2004). Kisii Central district, there are 59 registered SACCOs of which 33.9 are active, 32.2 are semi active and 33.9 are dormant, The large number of inactive SACCOs is as a result of decline in performance of employees, mismanagement, liberalization and loss of employee confidence mainly associated to poor and sometimes lack of performance appraisal (Ministry of Cooperatives Report - Kenya, 2004). It is in view of the aforementioned that the study is aimed at investigating the extent of implementation of performance appraisal in SACCOs in Kisii Central District.

\subsection{Statement of the problem}

Performance appraisal is a structured formal interaction between a subordinate and supervisor, that usually takes a form of periodic interview, in which the work performance of the subordinate is examined and discussed with a view to identifying weaknesses and strengths as well as reward outcomes, opportunities for improvement and skills development (Maina D.T. and Kibanga M, 2004).

Lack or poor performance appraisal in SACCOs has led to job insecurity, unprofessional process of recruitment that encourages favoritism, tribalism, and nepotism which sometimes attracts incompetent personnel. There have also been instances of illegal dismissal of employed staff, absence of appropriate personnel and administrative policies, job descriptions and specifications compounding the problems of governance in SACCOs (Mudibo E. K, 2005).

Despite the elaborate specification on appraisals and other human resource practices in organizations, the extent of implementation of performance appraisal in SACCOs, in Kenya, is not well documented. Therefore the purpose of this study was to investigate the extent of implementation of performance appraisal in SACCOs in Kisii Central District with an aim of determining the need for creating awareness.

\subsection{Literature Review}

\subsection{Strategy Implementation on Organization Performance}

Improvement in the performance of an organization accrues when its workforce is competent and performs at an optimum level (Bernardin \& Wiatrowski, 2013). Walker, Damanpour, \& Devece, (2011) argue that the new interest in the human resource as a strategic lever has a significant economic effect on the firm and there is need to shift the focus to value creation. Performance appraisal and management are the essences of organizational growth. A performance evaluation is a systematic process through which managers determine job-relevant strengths through identification, observation, measurement, and development (Kuvaas, 2006). It helps identify weaknesses in employees, measure and then developed. An accurate appraisal helps to diagnose the level of job performance through integrating human resource policies with the firm's strategic plan. Training and development programs are conducted to ensure that each task description is executed efficiently to improve the performance level of the human resource. Performance appraisals allow managers to make appropriate adjustments in the 
current performance levels. Performance management is a crucial tool for directors to advance competitiveness for their organization through creating a competitive edge with a highly 2 skilled labor force (Cameron, 2001). Through training and development, employees can perform efficiently and prepare for future challenges (Thurston, Wells, \& McNall, (2010).

Performance appraisals, managers are also able to make decisions on compensation adjustments and promotion for their human resource (Walker, Damanpour, \& Devece, 2011) Performance appraisal is a formal and systematic assessment of the performance of employees by managers and directors to understand the labor force regarding abilities to further growth. The process involves managers measuring and evaluating job-related behaviors of their employees and the outcomes to determine the level of employee performance and explanations and ways to improve the current levels of performance in future for the benefit of the organization (Walker, Damanpour, \& Devece, 2011).

Appraisals take a systematic approach where supervisors measure employee's remuneration against set targets and plans (Kuvaas, 2006). Directors then take into account factors influencing the results of the appraisals from the employees. The employers are then in a position to guide their labor force to improved performance. Kate (2008) argues that the primary purpose of the process is to at identify and manage the performance of the organization. Identification during the process of appraisal allows the manager to determine what areas of the job should be examined when measuring performance (Walker, Damanpour, \& Devece, 2011) Measurement is at the core of the assessment system (Murphy, \& Cleveland, 1991). It involves checking the strengths and weaknesses of employee performance and management of the process means that the system should be future oriented by giving the resource feedback to provide guidance and higher performance levels in future (Bernardin, \& Wiatrowski, 2013).

\subsection{Strategy Implementation Key Roles on Performance}

Performance appraisal implementation properly conducted has several key roles in the organization. They have used administratively to base decisions like transfers, promotions; demotions, termination, and rewards (DeNisi \& Pritchard, 2006). They are also used to identify the need for training for the human resource and the areas that require further development and training. Directors also use them to form a basis for constructing a system for rewards and bonuses, provide feedback on performance for the employees, and improve supervision since the supervisor is aware of the subordinate's performance. Since 3 promotion or bonuses are awarded using the outcomes of the appraisal, it guarantees fairness and reduces grievances among employees (Simmons \& Iles, 2001) Managers and directors can also use it to evaluate the effectiveness of early stage processes like recruitment, selection, and induction in the organization (DeNisi \& Pritchard, 2006)

\subsection{Critical Organizational Activities on Performance}

Appraisals serves as a tool for motivation as targets achieved are indicatosr of the efficiency of employees. It, therefore, motivates employees to perform better and improve their performance index. Organizational performance is an analysis of a firm's performance in comparison to the set goals and objectives. According to Walker, Damanpour, \& Devece, (2011) it is the actual output measured against the intended output of the organization. Key factors like financial performance, market outreach, and shareholder value performance are analyzed to determine the actual performance (Simmons \& Iles, 2001). In some cases like manufacturing product capacity performance may also be put into consideration. Watson (2016) agrees that organizational performance has to be measured as the overall effectiveness of a firm in meeting identified needs of departments in the company but emphasizes that the efforts should also focus on the ability to improve its capacity to address those needs adequately continuously. Organizational performance engages a set of persistent activities, towards set targets, and formulating suitable modifications to accomplish the set aims efficiently (Thurston, Wells, \& McNall, (2010). The recurring activities are often the primary role of leaders in organizations.

Leadership in an organization's hierarchy, it is imperative to know the determinants of organizational performance (Watson, 2016.) It allows managers to identify the key factors to prioritize to develop organizational performance. The analysis should enable managers to address deficiencies and use the information gained to improve the company systems when it comes to customer service, investor demands and employee motivation (Rock \& David 2015)

\subsection{Analysis of Organizational Performance}

A comprehensive analysis of organizational performance allows the firm to improve their performance in the present and stay relevant for the future. The definition assumes that the company has control over all factors and it can adjust to achieve improved performance. The definition has received heavy criticism for considering a narrow view of the issue. Rock and David (2015) criticize most studies for defining organizational performance as a variable dependent. The definitions seek to recognize 4 variables that result in variation in performance. However, such explanations ignore the fact that performance advantage, is competitively unstable, performance is 
surrounded by casual complexities and using data based on the memory of employees has its limitations as it is biased and often inaccurate (Bersin, 2013) Since these barriers are well known, acknowledging them but ignoring their contribution is not a wholesome definition (Schuler, Farr \& Smith, 2013). Inadequate supervision and training, lack of intelligence among workers, or low standards, though contribute to low performance are not the only contributing factors. However, the varying definitions of organizational performance agree that to maximize, and the company has output, it is important to put its employees first.

Performance appraisal systems began as simple methods of income justification, that is, appraisal was used to decide whether or not the salary or wage of an individual employee was justified (Bretz et al., 1992).

According to Carroll et al (1982), performance appraisal is a vehicle to validate and refine organizational actions such as selection, training; and provide feedback to employees with an eye on improving future performance. According to Scholtes (1988), the most effective performance appraisals not only involves a discussion between an employee and corresponding supervisor, but also examines the relationships between the evaluated worker and others with whom he may come in contact. So, for instance, instead of asking for anonymous evaluations from a colleague with whom the employee works on a regular basis, each can answer the question for the other of how to best provide mutual help. And they do so in a collaborative rather than competitive environment.

\subsubsection{Psychological challenges of performance appraisal on performance} i) Creation of confidence

Performance appraisal offers an excellent opportunity - perhaps the best that will ever occur for a supervisor and a subordinate to recognize and agree upon individual training and development needs (Maina D.T. and Kibanga M, 2004). During the discussion of an employee work performance the presence or absence of work skills can become very obvious - even to those who habitually reject the idea of training for them. Performance appraisal can make the need for training more pressing and relevant by linking it clearly to performance outcomes and future career aspirations.

From the point of view of the organizations as a whole consolidated appraisal data can form a picture of the overall demand for training. This data may be analyzed by variables such as sex, department and so forth. In this respect, performance appraisal can provide a regular and efficient training needs audit for the entire organization. The overall result is that the employees are able to have confidence when carrying out their duties as a result of having increased knowledge through training and development (Maina D.T. and Kibanga M, 2004).

\section{ii) Tension Creation}

Though often understated or even denied, evaluation is a legitimate and major objective of performance appraisal. But the need to evaluate is also an ongoing source of tension since evaluative and developmental priorities appear to clash frequently. Yet at its most basic level performance appraisal is the process of examining and evaluating the performance of an individual. Though organizations have a clear right some would say duty to conduct such evaluations of performance many still recoil from the idea. To them the explicit process of judgment can be dehumanizing and demoralizing and a source of anxiety and distress to employees (Akiran, 1999).

\section{iii) Frustration}

The study of Taylor and Pearce (2005) reported that in -groupers are subordinates who seem to be favoured by their supervisors. In their relationship with the boss, they enjoy "a high degree of trust, interaction, support and rewards". On the other hand out-groupers don't do as well. They appear to be permanently out of favour and likely to bear the brunt of supervisory distrust and criticism. The effect is therefore similar to the halo effect; supervisors tend to judge employees as either good or bad and then search for evidence that supports that opinion. It was found that when in-groupers performed poorly on a task, supervisors tended to overlook the failure or attribute it to causes such as bad luck or bad timing; when they did well and their success was attributed to effort and ability. When out groupers performed poorly, there was little hesitation in citing the causes as laziness or incompetence. It is not clear how supervisors make the distinction between in-groupers and out-groupers. Whatever the criteria, it is clearly not objective, equitable or reliable. This bias must inevitably lead to a distortion of appraisal process. It must also be a source of frustration for those employees who are discriminated against.

\section{iv) Fear and Lack of Trust}

There is a degree of fear associated with the appraisal system. There is lack of trust in one's boss and management in general and this leads to phenomenon known as 'malicious compliance', that 'is a passive aggressive stance of "tell me when you want me to do and I'll do it" on the part of the employee (Griffin, 1989).

\section{v) Morale and Motivation}

When employees get a positive performance appraisal their morale levels are highly boosted. They are motivated to work harder towards achieving the organizational goals. However, there are penalties such as absenteeism and high turnover of staff that are paid due to the decrease of morale and motivation. These are deemed severe especially when the performance appraisal system is seen as "bad or unfair". An element of unfairness is the use of performance appraisal systems to punish or reward people for what are natural variations in the process of performance. This means that people are praised and rewarded or cursed and punished for factors beyond their power to influence let alone control (Keith, 1989). 
In addition the morale and motivation may not be brought about by an increase in salary as a result of positive performance appraisal (Hammer, 1993). The principle of increased pay based on performance appraisal seems to have as many supporters as detractors. It has been argued that it demotivates rather than motivates (Keith 1989) because more than 95 of all employees view themselves as above average and feel cheated when they get a lower than expected salary increase. In addition pay is merely "hygiene factor" or potential dissatisfy and not a motivator (Hammer, 1993)

\section{vi) Dissatisfaction}

Many employees experience dissatisfaction especially when they perceive that their employers are using the system to punish workers instead of helping them develop. Another common complaint is that managers fail to explain to employees what they expect from them or clearly define the standards and criteria they use to evaluate performance. Dissatisfaction can also occur as a result of personal prejudice, which is a rater's dislike for a group or class of people. When such a rater conducts performance appraisal he or she may distort the ratings of the appraisees (Hall \& Goodale, 1986). For example some human resource departments have noticed that male supervisors give undeservedly low ratings to those women who hold traditional male jobs.

\subsubsection{The social challenges of performance appraisal on Performance \\ i) Lack of teamwork}

Individuals may not put in too much effort in their work to be appraised because they feel that the supervisor doesn't know how well he or she is doing on the team, hence the appraisal system needs to be made team friendly (Hall \& Goodale, 1986).

ii) Increased interaction between supervisors and subordinates

Perhaps the most significant benefit is that in the rush and bustle of working life, it offers a rare chance for a supervisor and a subordinate to have "timeout" for a one - on - one discussion of importance work issues that might not otherwise be addressed. Almost universally where performance appraisal is conducted properly, both Supervisors and subordinates have reported their experience as beneficial and positive. Appraisal offers a valuable opportunity to focus on work activities and goals to identify and correct existing problems and encourage better future performance. Thus the performance of the whole organization is enhanced. For many employees, an official appraisal interview may be the only time they get to have exclusive, uninterrupted access to their supervisor. Said one employee of a large organization after his first formal performance appraisal, 'In twenty years of work, that's the first, time anyone has ever bothered to sit down and tell me how I'm doing". The value of this intense and purposeful interaction between a supervisor and a subordinate should not be underestimated (Maina D.T. and Kibanga M,2004).

\section{iii) Improved Communication}

Through appraisal, supervisors and subordinates get to discover areas where there may have been conflict due to breakdown of communication. They discuss problems openly hence opening up channels of proper communication (Ivancechi, 1987).

\section{iv) Rivalry}

An adverse effect of performance appraisal is that it can lead to workplace disruption and soured relationships between supervisors and subordinates. The subordinate ends up being uncooperative and unfriendly to the supervisors (Hall \& Goodale, 1986). Rivalry between supervisors and subordinates may occur if management is not honest with average or below average performers, rating them higher than they deserve. This is because it is unfair to the poor performers, rating them higher than they deserve. Equally, it is unfair to the poor performers and outstanding performers. Other situations that may result in rivalry and soured relationships are: average and outstanding employees are financially rewarded almost the same or promoted over higher performing employees and assignments change but the individual performance plans are not adjusted accordingly.

\section{iv) Performance appraisal shock and creation of a defensive attitude}

Performance appraisal shock occurs where the employee receives feedback he or she does not expect (Hammer, 1993). A defensive attitude is created when the employee does not perceive the feedback to be true and believes that his/her abilities to perform on the job are "in order" but that there is a conspiracy unfolding in order for the organization to get rid of the employee. In order to avoid performance appraisal shock and creation of a defensive attitude a few recommendations have been made by (Ivancechi, 1987).

These recommendations include:

\section{a) Train supervisors}

A critical step in the performance appraisal process is training supervisors (or other raters) so that they prepare fair and accurate appraisals and effectively communicate the evaluation to the employee. If this is not done the employees will feel that the supervisors are not being fair and as a result will not accept their feedback in a positive manner.

\section{b) Discuss methods with employees}

Prior to the appraisal interview supervisors should discuss with employees the method that will be used. This discussion should specify which areas of performance are evaluated, how often the evaluation takes place and it's 
significance to the employee. This prevents performance shock from occurring since the employees are able to understand how the results pertaining to their performance have been arrived at.

\section{c) Appraise according to job standards}

The performance appraisal should evaluate the employee's work according to ' the predetermined work requirements. Comparison with specific requirements indicates that the employee has or has not done well. The supervisor's feelings about the employee should not affect the employee and should not affect the appraisal. This ensures that the employees do not view their supervisors as trying to be against them and hence defensive behavior will not be created on their part.

\section{d) Discuss Appraisal with Employees}

In some organizations appraisal discussions are omitted whenever specific evaluative objectives for merit raises or promotions have been met. The general trend however is to make sure the supervisors discuss the appraisal with employees allowing employees to discuss the areas of agreement and disagreement. This ensures that the employees can determine what areas of their work to improve on and in addition perceive their appraisals as being fair.

\subsection{Critical Review of Major Issues}

Majority of the aforementioned researchers and authors have pointed out the role of performance appraisal and the challenges of implementing the system on organizational performance. It is therefore important that apart from setting up of targets, job description by the supervisors, it would be realistic that the prescribed targets should be discussed and agreed upon by the managers and subordinates if desirable results are to be achieved (lvancechi, 1987).

The observation by Maina D.T. and Kibanga M, 2004 that irregular appraisal often escalates dissatisfaction among employees which impact negatively on organization service delivery is realistic. However the study does not analyze the aftermath of a regular and systematic appraisal if the results of the appraisal are not addressed promptly. For failing to institute a pro-active measures on the appraisal results renders the process futile and negatively affect the morale of the hard working employees who may feel their contribution is not recognized by the organization.

Performance appraisal provides means of control over employee's job performance and offer individual and organizational productivity (behaviour goals). That sanction is the granting or withdrawing of economic rewards, opportunities for advancement and promotion and in the case of totally unsatisfactory performance, dismissal from the organization. What is assumed is that there is direct relationship between conducting performance appraisals and maintaining or improving an individual's contribution to the organization (Becker et aI., 1996).

\subsection{Summary and Gaps to be filled by the Study}

Appraisals are essential for the effective management and evaluation of the staff in a given organization. It helps to develop individuals, improve organizational performance and fit into business planning. Formal, performance appraisals are generally conducted annually for all the staff in the organization. Annual appraisals enable management to monitor agreed standards, expectations and objectives and delegation of tasks and responsibilities. Appraisals also establish individual training needs analysis and planning. In short, performance and job appraisals are important for managing the performance of people and organizations. In view of the aforementioned, this study was aimed at finding out whether there is direct relationship between implementing appraisals and improving organizational performance besides facing challenges in the process of implementation.

\subsection{METHODOLOGY}

\subsection{Study Design}

The descriptive survey method was adopted to conduct the study. It was relevant because it is used to assess attitudes and opinions about events, individuals or procedures (Gay, 1992). The design is in agreement with the views of Orodho, (2004) and those of Lockesh,(1984) who contend that descriptive research studies are designed to obtain pertinent and precise information concerning the current status of a phenomena and whenever possible to draw valid conclusions from facts discovered.

\subsection{Target population}

The study population comprised of all the 165 regular SACCO employees of the active SACCOS in Kisii Central District, Kenya. According to Gay (1992), a researcher selects a sample due to various limitations that may not allow researching the whole population. Mugenda and Mugenda (1999) notes that resource and time tend to be major constraints in deciding on the sample size to use.

\subsubsection{Active SACCOs}

The sample of active SACCOs emanates from Mulusa, (1990) who suggests that one third of the target population is representative enough to make estimate of characteristics being investigated. Hence out of the twenty (20) active 
SACCOs in Kisii Central District one third was seven SACCOs, that were randomly sampled (Table 1)

Table 1: Active SACCOs, which were randomly sampled

\begin{tabular}{|l|l|l|l|}
\hline Name of SACCO & \multicolumn{2}{l|}{ No. of employees } & Total \\
\hline & Male & Female & \\
\hline KISIBOS & 3 & 1 & 4 \\
\hline GUSSACCO & 85 & 20 & 105 \\
\hline KISII F.C.U & 11 & 5 & 16 \\
\hline GUSII MW ALIMU & 21 & 13 & 33 \\
\hline SANSORA & 2 & 1 & 3 \\
\hline NASS & & \multicolumn{2}{l}{} \\
\hline GUBOGIS & 0 & 2 & 2 \\
\hline TOTALS & 1 & 0 & 1 \\
\hline
\end{tabular}

\section{SACCO employees}

The sample of SACCO employees were done according to Mulusa (1990) who suggests that one third of the target population is representative enough to generalize characteristics being investigated. Therefore one third of the total population was 55 .

\subsection{Sampling Design}

Using stratified sampling the SACCO employees were divided according to job designation and gender. This gave rise to 43 males and 12 females. Stratified sampling helped to achieve desired representation of various subject population as supported by Mugenda and Mugenda (1990).

\subsubsection{Piloting of the study}

The researcher carried out piloting at Gusii Mwalimu SACCO using stratified sampling, one third of the employees (11) from various cadres, was picked to fill questionnaires. All these questionnaires were not included in the main study sample. Piloting helps to determine validity, and reliability of the research instrument. Any weaknesses that were evident were corrected. This helped the researcher to determine whether the respondents understood the questions.

\subsubsection{Validity}

The research instrument was validated through the application of content validity procedures. According to Tyler (1971) this is a judgment made better by a team of professionals and in this connection, the researcher established content validity by seeking expert judgment from his supervisors while developing and revising the research instrument. This was done by holding discussions, making relevant comments and suggestions that were synchronized.

\subsubsection{Reliability}

The questionnaire was tested for reliability to the specific situations whereby the coefficient of internal consistency of the split half reliability method was used. The questionnaire was administered to the pilot group and then, the scores were ranked. The scores were divided into two equal sets and each subjects score was computed. Dividing the questionnaires into two comparable half, the spearman Brow proficiency formula ( $\mathrm{R}$ split - half) was used to correlate the two as shown: -

$\mathrm{R}($ Total test $)=2($ split - half $)=2(0.77) \quad=0.87$

$1+$ (split - halt) $1+(0.77)$

According to Gay (1982); an instrument with a split half estimate between 0.8 and 1 is acceptable as reliable and can be administered to respondents.

\subsection{Data Collection Procedures}

The study used questionnaires as the main instruments to collect data. As' Best and Khan (1992) notes that questionnaires enable the person administering them to explain the purpose of study and give meaning of items that may not be clear. In addition questionnaires are suitable in collecting the required important information from a large number of respondents. The questionnaire was used to elicit information on the extent of implementation of performance appraisal by the SACCOs' management. The instrument contained both open - ended and close ended questions. The open - ended items, gave the respondents more freedom to express their views or opinions and also make suggestions. Close-ended items guided the respondents to give specific responses as given by the researcher.

This instrument comprised of parts A and B. Part A determined background information such as age, gender, and job designation. Part B determined the extent of implementation of performance appraisal by the SACCOs' management. Permission was sought from the Ministry of Education and the Ministry of co-operatives (Kenya). The researcher made preliminary visits to the randomly sampled SACCOs to explain the purpose of the study 
verbally and made the necessary arrangements for the administration of questionnaires and data collection. The researcher self - administered' the questionnaires to each of the respondents and collected them after two weeks. This ensured achievement of a good return ratio and helped respondents to get a chance to seek clarification on items that proved to be difficult. Documentation analysis was done by the researcher.

\subsection{Data Analysis}

On completion of data collection the researcher checked for completeness of the filled questionnaires and coded them. The data was then arranged and grouped according to particular research questions. This data was tabulated and analyzed using descriptive and inferential statistics by Software Package for Social Sciences. This is according to Harper, (1998) who observes that use of a tabular layout enables any desired figures to be located more quickly and makes comparison between different categories to be made more easily. According to Juma and Ngome (1998) coding categories is developed as a way of organizing the qualitative data collected according to particular research questions. This involves going through the data and numbering it sequentially, carefully searching for regularities and patterning relation to research questions. The words and phrases are the coding categories and are used as a means of sorting out the descriptive data.

\subsection{RESULTS}

\subsection{Quantitative Analysis}

Table 2: Number of respondents

\begin{tabular}{|l|l|l|}
\hline Questionnaire & Frequency & Percentage (\%) \\
\hline Respondents & 50 & 90.9 \\
\hline Non-respondents & 5 & 9.1 \\
\hline Total & 55 & 100 \\
\hline
\end{tabular}

Questionnaires were issued to the respondents and 90.9 were collected while 9.1 were not returned.

Table 3: Gender of respondents

\begin{tabular}{|l|l|l|}
\hline Gender & Frequency & Percentage \\
\hline Male & 40 & 80.0 \\
\hline Female & 10 & 20.0 \\
\hline Total & 50 & 100 \\
\hline
\end{tabular}

Majority of the respondents (80) were males whereas (20) were females.

Table 4Age brackets of the respondents.

\begin{tabular}{|l|l|l|}
\hline Age bracket (years) & Frequency & Percentage \\
\hline $18-28$ & 11 & 22.0 \\
\hline $29-39$ & 20 & 40.0 \\
\hline $40-49$ & 6 & 12.0 \\
\hline Above 50 & 13 & 26.0 \\
\hline Total & 50 & 100.0 \\
\hline
\end{tabular}

The majority of the respondents (40) had between 29-39 years, whereas 12 had between 40-49 years, 22had between 18-28 years. The other respondents were above 50 years.

Table 5 Level of education of the respondents

\begin{tabular}{|l|l|l|}
\hline Educational level & Frequency & Percentage \\
\hline Primary education certificate & 2 & 4.0 \\
\hline Secondary/high school certificate & 10 & 20.0 \\
\hline Post-secondary certificate & 10 & 20.0 \\
\hline Post-secondary Diploma & 13 & 26.0 \\
\hline Undergraduate degree & 10 & 20.0 \\
\hline Postgraduate degree & 5 & 10.0 \\
\hline Total & 50 & 100.0 \\
\hline
\end{tabular}

The majority of the respondents were holders of post-secondary, diploma or undergraduate degree (46). Secondary and high school certificate holders or post-secondary certificate holders comprised of 24 of the respondents. Postgraduate degree holders comprised of 10 while the minority consisted of primary education certificate (4). 
Table 6 Terms of employment of respondents

\begin{tabular}{|l|l|l|}
\hline Employment terms & Frequency & Percentage \\
\hline Probation & 2 & 4.0 \\
\hline Permanent & 2 & 4.0 \\
\hline Temporal & 39 & 78.0 \\
\hline Contract & 7 & 14.0 \\
\hline Total & 50 & 100.0 \\
\hline
\end{tabular}

Mainly, the respondents were on temporal terms of employment (78) whereas those employed on probation and contract terms were 18 and only 4 of the respondents were on permanent and pensionable terms.

Table 7 Period respondents had worked in the same SACCO

\begin{tabular}{|l|l|l|}
\hline Time (years) & Frequency & Percentage \\
\hline Less 5 & 13 & 26.0 \\
\hline $6-10$ & 19 & 38.0 \\
\hline $11-15$ & 12 & 24.0 \\
\hline Above 16 & 6 & 12 \\
\hline Total & 50 & 100.0 \\
\hline
\end{tabular}

The study established that 38 of the respondents had worked in the same SACCO for a period of between 610 years. Those who had worked for less than 5 years comprised of 26 whereas 24 of the respondents had worked for the same SACCO for a period of between 11 - 15 years. A minority 12 had stayed with the same SACCO for a period of more than 16 years.

Table 8 Designation of the respondents

\begin{tabular}{|l|l|l|}
\hline Designation & Frequency & Percentage \\
\hline General/Deputy & 2 & 4.0 \\
\hline Head of Department & 14 & 28.0 \\
\hline Clerk & 18 & 36.0 \\
\hline Branch Manager & 6 & 12.0 \\
\hline Supervisor & 7 & 14.0 \\
\hline Office Messenger & 3 & 6.0 \\
\hline Total & 50 & 100.0 \\
\hline
\end{tabular}

Majority of the respondents (36) comprised of clerks, heads of departments formed the next bulk of respondents (28) while office messengers comprised of 6 . General managers, deputy managers, Branch managers and supervisors comprised of 30 of the respondents.

Table 9 The job grade/group of respondents

\begin{tabular}{|l|l|l|}
\hline Job grade & Frequency & Percentage \\
\hline 16 & $1 \sim$ & 2.0 \\
\hline 15 & 4 & 8.0 \\
\hline 14 & 8 & 16.0 \\
\hline 13 & 6 & 12.0 \\
\hline 12 & 4 & 8.0 \\
\hline 11 & 2 & 4.0 \\
\hline 10 & 8 & 16.0 \\
\hline 9 & 3 & 6.0 \\
\hline 7 & 2 & 4.0 \\
\hline Others & 12 & 24.0 \\
\hline Total & 50 & 100.0 \\
\hline Majority of thespond
\end{tabular}

Majority of the respondents were between job grade 11 to 14 (40), followed by job grade 7 - 10 (26), job grade 15 and 16 comprised of 10 . The other respondents (24) did not belong to any specified group.

Table 10 Period respondents had been in the same job grade.

\begin{tabular}{|l|l|l|}
\hline Time (years) & Frequency & Percentage \\
\hline Less 5 & 26 & 52.0 \\
\hline $6-10$ & 10 & 20.0 \\
\hline $11-15$ & 6 & 12.0 \\
\hline Above 16 & 8 & 16.0 \\
\hline Total & 50 & 100.0 \\
\hline
\end{tabular}

The study established that majority of the respondents (52) had been in the same job grade for a period of less than 5 years, whereas 20 of the respondents had stayed in the same job grade for a period-of 6-10 years. Another portion of the respondents (12) had stayed in the same job grade for a period of $11-15$ years whereas 16 of the 
respondents had been in the same job grade for over 16 years.

Table 11 Salary brackets of respondents

\begin{tabular}{|l|l|l|}
\hline Salary Bracket (K.shs) & Frequency & Percentage \\
\hline Less 7000 & 6 & 12.0 \\
$7001-17000$ & 22 & 44.0 \\
$17001-27000$ & 6 & 12.0 \\
$27001-37000$ & 6 & 12.0 \\
$37001-47000$ & 6 & 12.0 \\
$47001-57000$ & 3 & 6.0 \\
$57001-67000$ & 1 & 2.0 \\
Total & $\mathbf{5 0}$ & $\mathbf{1 0 0 . 0}$ \\
\hline
\end{tabular}

Majority of the respondents (68) earned a salary of between Kshs (7,000 to 37,000) whereas 20 of the respondents earned a salary of between Kshs. (37,000 and 67,000). Only 12 of the respondents earned a salary of below Kshs 7,000.

Table 12 Period when salary was last reviewed

\begin{tabular}{|l|l|l|}
\hline Time (years) & Frequency & Percentage \\
\hline Less 5 & 30 & 60.0 \\
$6-10$ & 15 & 30.0 \\
$11-15$ & 5 & 10.0 \\
\hline Total & $\mathbf{5 0}$ & $\mathbf{1 0 0 . 0}$ \\
\hline
\end{tabular}

The study indicates that majority of the respondents (60) had their salaries reviewed more than six years ago. The other lot of 40 of the respondents had their salaries reviewed in a period less than five years.

\subsection{QUALITATIVE ANALYSIS}

Table 13 Availability of performance Appraisal

\begin{tabular}{|l|l|l|}
\hline Performance Appraisal availability & Frequency & Percentage \\
\hline Yes & 12 & 24.0 \\
\hline No & 38 & 76.0 \\
\hline Total & 50 & 100.0 \\
\hline
\end{tabular}

Majority of the respondents (76) indicated that they did not have performance appraisal in their SACCOs whereas only 24 of the respondents showed that they had performance appraisal.

Table 14 Officers who carry out performance appraisal

\begin{tabular}{|l|l|l|}
\hline Officer & Frequency & Percentage \\
\hline Board Of Directors & 2 & 16.7 \\
\hline DeputyGeneral Manager & 1 & 8.3 \\
\hline Head of Department & 2 & 16.7 \\
\hline Peer & 2 & 16.7 \\
\hline General manager & 4 & 33.3 \\
\hline Others & 1 & 8.3 \\
\hline Total & 12 & 100 \\
\hline
\end{tabular}

For the SACCO, that had performance appraisal, the study indicated that it is largely carried out by the general managers (33.3), followed by the Board of directors, the deputy general managers and the heads of department (16.7). Peers who carried out performance appraisal comprised of 16.7. The rest (8.3) was carried out by unspecified personnel. 
Table 15 Frequency of carrying out performance appraisal

\begin{tabular}{|l|l|l|}
\hline Time (years) & Frequency & Percentage \\
\hline Once & 8 & 66.7 \\
\hline Twice & 3 & 25.0 \\
\hline Thrice & 1 & 8.3 \\
\hline Total & 12 & 100 \\
\hline
\end{tabular}

For the SACCOs that carried out performance appraisal, the study showed that it is mainly done once a year 66.7; while 25 of the SACCOs carried it out twice a year. Only 8.3 of the SACCOs carry out performance appraisal thrice a year.

Table 16: The extent to which performance appraisal is used by SACCOs to measure workers strengths and weaknesses

\begin{tabular}{|l|l|l|l|l|l|l|l|}
\hline $\begin{array}{l}\text { Rating/ areas } \\
\text { assessed }\end{array}$ & $\begin{array}{l}\text { Very } \\
\text { great } \\
\text { extent } \\
(4)\end{array}$ & $\begin{array}{l}\text { A great } \\
\text { extent } \\
(3)\end{array}$ & $\begin{array}{l}\text { Less } \\
\text { extent } \\
(2)\end{array}$ & $\begin{array}{l}\text { Least } \\
\text { extent }\end{array}$ & $\sum \mathrm{f}$ & $\sum \mathrm{wf}$ & $\begin{array}{l}\sum \mathrm{wf} \\
\sum \mathrm{f}\end{array}$ \\
\hline Knowledge of work & 3 & 6 & 2 & 1 & 12 & 35 & 2.92 \\
\hline Quality of work & 2 & 5 & 4 & 1 & 12 & 32 & 2.67 \\
\hline Quantity of work & 1 & 6 & 4 & 1 & 12 & 31 & 2.58 \\
\hline Ability of work & 2 & 4 & 4 & 2 & 12 & 30 & 2.50 \\
\hline Ability to cooperate & 2 & 5 & 4 & 1 & 12 & 32 & 2.67 \\
\hline Diligence & 1 & 6 & 4 & 1 & 12 & 31 & 2.58 \\
\hline Morale & 1 & 6 & 5 & 0 & 12 & 32 & 2.67 \\
\hline Discipline & 1 & 5 & 4 & 2 & 12 & 29 & 2.42 \\
\hline Conduct/behavior & 1 & 6 & 5 & 0 & 12 & 32 & 2.67 \\
\hline Communication & 1 & 5 & 5 & 1 & 12 & 30 & 2.50 \\
\hline Job experience & 1 & 5 & 6 & 0 & 12 & 31 & 2.58 \\
\hline Personal judgment & 1 & 4 & 5 & 2 & 12 & 25 & 2.08 \\
\hline $\begin{array}{l}\text { Attainment } \\
\text { SACCO goals }\end{array}$ & 1 & 4 & 6 & 1 & 12 & 29 & 2.42 \\
\hline $\begin{array}{l}\text { Improvement } \\
\text { workmanship }\end{array}$ & 1 & 4 & 7 & 0 & 12 & 30 & 2.50 \\
\hline
\end{tabular}

The study revealed that, the extent to which assessment of workers' strengths and weaknesses such as; knowledge of work (2.92) quality of work (2.67) quantity of work (2.58), ability to co-operate (2.67) diligence (2.58), morale (2.67), were rated as to a great extent (3.0) on a Likert scale of 1 to 4 with 4 being the best (very great extent). Other strengths such as communication (2.50) Ability of work (2.50), job experience (2.42), personal judgment (2.08), attainment of SACCO goals (2.42) and improvement of workmanship (2.50) were rated to a less extent on the, same scale.

Table 17 Extent to which performance appraisal is used by SACCOs to overcome challenges at work.

\begin{tabular}{|c|c|c|c|c|c|c|c|c|}
\hline Rating challenges & $\begin{array}{l}\text { Most } \\
\text { effective } \\
(5)\end{array}$ & $\begin{array}{l}\text { More } \\
\text { Effective } \\
(4)\end{array}$ & $\begin{array}{l}\text { Effective } \\
\text { (3) }\end{array}$ & $\begin{array}{l}\text { Infective } \\
\text { (2) }\end{array}$ & $\begin{array}{l}\text { Most } \\
\text { Infective } \\
(1)\end{array}$ & $\sum \mathrm{f}$ & $\begin{array}{l}\sum_{\mathrm{f}} \mathrm{w} \\
\end{array}$ & $\begin{array}{l}\frac{\sum w f}{} \\
\sum f f\end{array}$ \\
\hline $\begin{array}{l}\text { Confidence } \\
\text { Creation }\end{array}$ & 2 & 3 & 3 & 3 & 1 & 12 & 38 & 3.17 \\
\hline Tension & 1 & 2 & 4 & 4 & 1 & 12 & 34 & 2.83 \\
\hline Frustration & 1 & 2 & 4 & 3 & 2 & 12 & 33 & 2.75 \\
\hline Fear/Mistrust & 1 & 2 & 4 & 4 & 1 & 12 & 34 & 2.83 \\
\hline Low motivation & 0 & 1 & 5 & 5 & 1 & 12 & 30 & 2.50 \\
\hline Job satisfaction & 1 & 1 & 4 & 4 & 2 & 12 & 31 & 2.58 \\
\hline $\begin{array}{l}\text { Lack of team } \\
\text { work }\end{array}$ & 0 & 2 & 5 & 3 & 2 & 12 & 31 & 2.58 \\
\hline Indiscipline & 0 & 1 & 6 & 4 & 1 & 12 & 31 & 2.58 \\
\hline $\begin{array}{l}\text { Poor } \\
\text { Communication }\end{array}$ & 0 & 1 & 6 & 3 & 2 & 12 & 30 & 2.58 \\
\hline Rivalry & 0 & 2 & 3 & 4 & 3 & 12 & 28 & 2.33 \\
\hline
\end{tabular}


The study showed that, the extent to which performance appraisal is used to overcome challenges at work was effective (3.0) by using the following features; confidence creation (3.17), tension at work (2.83), frustrations at work (2.75), fear and mistrust (2.83), job satisfaction (2.58), lack of teamwork (2.58) indiscipline (2.58) on a likert scale of 1 to 5 with 5 being the best (Most effective) whereas on poor communication (2.50), low motivation (2.50) and work rivalry (2.33) it was rated as ineffective (2.0) on the same scale.

Table 18: Extent to which performance appraisal is used by SACCOs in decision making

\begin{tabular}{|l|l|l|l|l|l|l|l|}
\hline Use of PAS/extent & $\begin{array}{l}\text { Very great } \\
\text { extent (4) }\end{array}$ & $\begin{array}{l}\text { A great } \\
\text { extent(3) }\end{array}$ & $\begin{array}{l}\text { Less } \\
\text { extent (2) }\end{array}$ & Never(1) & $\sum \mathrm{f}$ & $\sum \mathrm{w} f$ & $\begin{array}{l}\sum \mathrm{wf} \\
\sum \mathrm{f}\end{array}$ \\
\hline Layoffs/Retrenchments & 0 & 3 & 6 & 3 & 12 & 24 & 2.0 \\
\hline Confidence creation & 0 & 4 & 5 & 3 & 12 & 25 & 2.08 \\
\hline Promotions & 1 & 4 & 5 & 2 & 12 & 28 & 2.33 \\
\hline Pay increase & 1 & 4 & 5 & 2 & 12 & 28 & 2.33 \\
\hline Certificates & 1 & 5 & 5 & 1 & 12 & 30 & 2.50 \\
\hline Training Opportunities & 1 & 3 & 4 & 4 & 12 & 35 & 2.08 \\
\hline $\begin{array}{l}\text { Increased Interaction } \\
\text { between supervisors and } \\
\text { subordinates }\end{array}$ & 1 & 5 & 5 & 1 & 12 & 30 & 2.50 \\
\hline Appreciation & & & & & & \\
\hline
\end{tabular}

The study showed that decisions that affected the respondents such as promotion (2.33), layoffs/retrenchments (2.00), pay increase (2.33), appreciation (2.42), certification (2.50), training opportunities (2.08), increased interaction between supervisors and subordinates (2.50), and confidence creation (2.08) depended on performance appraisal to a less extent (2.0).

Table 19: Rating the challenges in implementing performance appraisal in SACCOs

\begin{tabular}{|l|l|l|l|l|l|l|l|l|}
\hline $\begin{array}{l}\text { Challenges of } \\
\text { performance } \\
\text { appraisal }\end{array}$ & $\begin{array}{l}\text { Largest } \\
\text { extent (5) }\end{array}$ & $\begin{array}{l}\text { Larger } \\
\text { extent (4) }\end{array}$ & $\begin{array}{l}\text { Large } \\
\text { extent } \\
(3)\end{array}$ & $\begin{array}{l}\text { Less extent } \\
(2)\end{array}$ & $\begin{array}{l}\text { Least } \\
\text { extent } \\
(1)\end{array}$ & $\sum \mathrm{f}$ & $\sum \mathrm{w} \mathrm{f}$ & $\begin{array}{l}\sum \mathrm{wf} \\
\sum \mathrm{f}\end{array}$ \\
\hline Distinctiveness & 1 & 2 & 3 & 5 & 1 & 12 & 33 & 2.75 \\
\hline Visibility & 1 & 2 & 6 & 2 & 1 & 12 & 36 & 3.00 \\
\hline Legitimacy & 1 & 2 & 6 & 3 & 0 & 12 & 37 & 3.08 \\
\hline Relevance & 1 & 2 & 3 & 6 & 0 & 12 & 34 & 2.83 \\
\hline Instrumentality & 1 & 2 & 6 & 2 & 2 & 12 & 37 & 3.08 \\
\hline Consistency & 1 & 2 & 5 & 4 & 0 & 12 & 36 & 3.00 \\
\hline Validity & 0 & 2 & 6 & 4 & 0 & 12 & 34 & 2.83 \\
\hline Consensus & 1 & 1 & 8 & 2 & 0 & 12 & 37 & 3.08 \\
\hline Fairness & 1 & 1 & 6 & 3 & 1 & 12 & 34 & 2.83 \\
\hline Suitability & 0 & 2 & 6 & 2 & 2 & 12 & 32 & 2.67 \\
\hline
\end{tabular}

The study showed that the challenges experienced in implementing performance appraisal in SACCOs are to a large extent (3.0). The parameters that were used in this measure were as follows: distinctiveness of the performance appraisal (2.75), visibility (3.00), legitimacy (3.08),

Relevancy (2.83), instrumentality (3.08), consistency of use (3.00), validity (2.83), consensus (3.08), fairness of the system (2.83) and suitability of the document (2.67)

\subsection{Summary of Data Analysis}

The researcher had 50 respondents of which 40 were male and 10 females. The researcher established that most of the respondents lay within the active age brackets of 29-50 years and most of them had, attained an education level of secondary school certificate and above. The research indicated that most workers were employed on temporal terms and they had been in the same job grade for a period of more than 5 years. Majority of the respondents were clerks and heads of department who were in job grade 13-14. The research established that most workers rarely stayed in the same job grade for a period of more than 5 years and their salaries were frequently reviewed.

The researcher further established that there was a small proportion of SACCOs using performance appraisal and the appraisal was mostly conducted by the General Managers once a year. The study revealed that, despite facing challenges of implementation to a large extent, performance appraisal was used to a less extent in measuring workers strengths and weaknesses and in decision making concerning their welfare and job mobility.

\subsection{FINDINGS, CONCLUSIONS AND RECOMMENDATIONS}

5.1 Summary of majority findings

The study showed that a large proportion of SACCOs (76.0) lacked performance appraisal. Those SACCOS that 
had performance appraisal (24), carried it out once a year and it was largely conducted by the general manager. To a less extent, the performance appraisal helped the, SACCOs to rate the workers' strengths and weaknesses. Although it was revealed that performance appraisal helped SACCOs in overcoming challenges at work; unfortunately, many SACCOs did not use it in implementing decisions that concerned workers welfare and job mobility.

\subsection{Answers to research question}

5.2.1 Proportion of SACCOs using performance appraisal

The research established that only (24)of the sampled SACCOs carried out performance appraisal.

5.2.2 How performance appraisal is conducted

The study revealed that performance appraisal was largely done by the general managers, board of directors, heads of departments and it was done once a year.

\subsubsection{Challenges of implementing performance appraisal}

The study showed that the challenges experienced in implementing performance appraisal in SACCOs were to a large extent in terms of distinctiveness, visibility, legitimacy, relevancy, instrumentality, consistency of use, validity, consensus, fairness of the system and suitability of the document.

\subsection{Conclusion}

A large proportion of SACCOs lack performance appraisal. Those SACCOS that have appraisals carry it out once a year. The appraisals help SACCOs to rate the workers' strengths and weaknesses and in, overcoming challenges at work. Only 24 the sampled SACCOs carried out performance appraisal. The challenges of implementing performance appraisal in SACCOs are to a large extent.

\subsection{Recommendations}

The Ministry of co-operatives should sensitize the SACCOs on the importance of using performance appraisal in appraising employees given that appraisals:from the supervisor

Provide employees with knowledge of their performance over time framework through feedback

ii) Identify strengths and areas of weaknesses in employee job performance.

iii) Provide opportunity for the supervisor and employee to meet face to face and clarify job expectations with a view to adding value to the SACCOs.

Iv Enable individual employees understand clearly where their performance matches or exceeds organizations expectations and where there are shortfalls. The ministry of co-operatives should also standardize performance appraisal and make them objective by providing uniform process and criteria. The ministry of co-operatives should ensure that employees of SACCOs' know how they are performing, their jobs by being given feedback on their performance and counselling them as appropriate.

\subsection{Suggestions for further study}

The researcher suggests further research in the following areas:

i) The role of work plans in performance appraisal in SACCOs.

ii) The economic effects of performance appraisal in SACCOs.

iii) Linkage of performance appraisal in SACCOs and other public service reforms.

\section{REFERENCES}

Akiran, N. (1999). An Improved Subordinate Appraisal of Bank Managers Competence. International Journal of Human Resource Management.

Best, J. and Khan, J. (1992). Research in Education. New Delhi: PrenticeHall.

Becker, Brian and Barry Gerhart (1996). The impact of human resource management on organizational performance: progress and prospects. Academy of Management Journal, vol. 39, No. 4 (August), pp. 779801; and M. Patterson,

M. West, R. Lawthorn and S. Nickell (1997).The impact of people. management practices on business performance. Issues in People Management, No. 22. London: Institute of Personnel and Development.

Bretz, R. D. Jr., Milkovich, G. T., \& Read, W. (1992). The current state of performance appraisal research and practice: Concerns, directions, and implications. Journal of Management: Carel, Nobert, Hatfield (1995). Human Resource Management: A Global Strategy for Managing a Diverse Work force, $\left(5^{\text {th }}\right.$ ed.) Prentice Hall Inc. New Jersey U.S.A.

Carina S. and Jennie O. (2001). A paper on Savings and credit Co- operatives in Kenya. A minor field study

Carroll, S. J., \& Schneier, C. E. (1982). Performance Appraisal and Review Systems: The Identification, Measurement, and Development of Performance in Organizations. Glenview, Illinois: Scott, Foresman, and 


\section{Company;}

Foster, B. (2004). "Performance Appraisal Competence Project" A paper presented in performance appraisal competence, committee workshop, September 2,2004, New Jersey, U.S.A.

Gay L. R, (1992). Education Research: Competencies for Analysis and Application (3 ${ }^{\text {rd }}$ ed.) Paris: Meru Publishing Company.

Griffin, M. (1989). Personnel Research on Testing Selection and Performance Appraisal. Public Personnel Management Journal Vol. 18, No.2, Summer, U.S.A.

Hall, D. T and Goodate, J. (1986).Human Resource Management.

Strategy Design and Implementation. Scott, Foresman and Company

Hammer, M. (1993). Re-engineering the co-operation - A Manifesto for Business New York U.S.A.

Harper, W. (1998). Statistics ( $5^{\text {th }}$ ed.) London; Longmann.

Ivancechi, J. (1987). Organizational Behaviour and Management. (4 ${ }^{\text {th }}$ ed.) Richard Win, U.S.A.

Juma, M. N and Ngome, C (1998). "Qualitative and Quantitative Research Data Analysis". A paper presented at Spred II base line and special studies workshop, April 27-28, 1998 in Naivasha.

Keith, S. (1989). Personnel Management. A Comprehensive Guide to Theory and Practice in Britain. Black well Publishers Inc. Massachusetts, U.S.A.

Kothari, C.R. (2004) Research methodology; methods and Techniques.

Wishwa Prakashan, Delhi.

Latham, G. P., \& Locke, E. A. (1983). Goal Setting-A Motivational Technique That Works. In Contemporary Problems in Personnel (3rd ed.) John Wiley \& Sons. New York:

Lokesh, K. (1984). Methodology of Educational Research. New Delhi: Van Educational Books.

Maina D.T and Kibanga M. (2004). Cooperative management in developing countries, Kenpak colour printers Ltd, Nairobi Kenya.

Mudibo E. K. (2005). A report on the East African experience presented during the 3,,1 Pan-African consultative forum on corporate governance in Dakar, Senegal S" - 10, h November, 2005

Mugenda, O. M. and Mugenda, A.G. \{I 999). Research Methods and Qualitative Approaches. Nairobi: Acts Press

Mulusa, T. (1990). Evaluating Education and Community Development programmes. Nairobi University Press.

Orodho A...J. (2004). Techniques of writing research proposals and reports in education and social sciences. Nairobi; Masola publishers.

Republic of Kenya, (2004). Status of SACCO movement in Kenya.

Government report, December 31 st.

Rodger, B. \{I 998). Human Resource Management. London, Britain.

Scholtes, P. R. \{I 988). The Team Handbook: How to Use Teams to Improve Quality. Joiner Associates.

Taylor, P. 1. and Pearce, J. L. (2005). "Effects of introducing a performance management system on employees' Subsequent attitudes and efforts". A paper presented at a performance management system conference, June, 2 -4 (2005 Minnesota U.S.A.

Tyler, R.W (1971) Educational research, Washington D.C P.B Publishers. 